American Journal of Biochemistry and Biotechnology 7 (4): 163-171, 2011

ISSN 1553-3468

(C) 2011 Y.L. Ma et al., This open access article is distributed under a Creative Commons Attribution

(CC-BY) 3.0 license

\title{
Fluctuation of Brain Tissue Oxygen \\ Partial Pressure: A Biochemical Landmark in the Arctic Ground Squirrel's Spontaneous Arousal
}

\author{
Yi Long Ma, Shu Fen Wu and Lawrence K. Duffy \\ Alaska Neuroscience Program, Institute of Arctic Biology, \\ University of Alaska Fairbanks, 902 N Koyukuk Dr, Fairbanks, 99775-7000, Alaska
}

\begin{abstract}
Hibernation in the Arctic Ground Squirrel (AGS) is a regulated, adaptive response to arctic environmental conditions. Problem statement: Regional brain Blood Flow (rCBF) has been observed to increase dramatically during arousal in hibernators. However, the real time dynamic change in $\mathrm{P}_{t} \mathrm{O}_{2}$ during arousal has not been studied, we hypothesized that $\mathrm{P}_{t} \mathrm{O}_{2}$ is Interdependent of $\mathrm{T}_{\text {brain }}$ and a key component in the arousal process. Approach: Simultaneous in vivo measurements of $\mathrm{P}_{\mathrm{t}} \mathrm{O}_{2}$ and brain temperature $\left(\mathrm{T}_{\text {brain }}\right)$ in conjunction with oxygen consumption $\left(\mathrm{V}_{02}\right)$ were conducted in the striatum of non-sedated, non-anesthetized Arctic ground squirrels during spontaneous arousal from hibernation. Results: A dramatic fluctuation of brain tissue oxygen partial pressure $\left(\mathrm{P}_{\mathrm{t}} \mathrm{O}_{2}\right)$ is associated with the complex phenomena of spontaneous arousal. In this study, we observed that: (1) a $\mathrm{P}_{t} \mathrm{O}_{2}$ elevation precedes changes in $\mathrm{T}_{\text {brain }}$ and $\mathrm{V}_{02}$; (2) $\mathrm{P}_{\mathrm{t}} \mathrm{O}_{2}$ changes do not correlate with changes in $\mathrm{V}_{02}$ during arousal and (3), endogenous $\mathrm{O}_{2}$ shift from $\mathrm{O}_{2}$ enriched blood to brain in hibernating AGS induces an arousal with the pharmaceutical chemical, efaproxiral (RSR-13). Conclusion: The four turning points of $\mathrm{P}_{t} \mathrm{O}_{2}$ appearing at different $\mathrm{T}_{\text {brain }}$ during arousal suggest that changes in $\mathrm{P}_{t} \mathrm{O}_{2}$ are $\mathrm{T}_{\text {brain }}$ interdependent and support the concept that arousal from hibernation is complex process invoking different feedbacks.
\end{abstract}

Key words: Arctic Ground Squirrel (AGS), Institutional Animal Care and Use (IAUC), Central Nervous System (CNS), blood oxygen partial

\section{INTRODUCTION}

Hibernation is a well regulated adaptive response to environmental conditions of low ambient temperature $\left(\mathrm{T}_{\mathrm{a}}\right)$ and food shortage during winter (Ortmann and Heldmaier, 2000; Jinka et al., 2011). Body temperature, metabolic rate, heart rate, blood pressure and cerebral blood flow are greatly reduced relative to resting euthermic state in natural hibernation (Osborne et al., 2005; Toien et al., 2011). A regulated body temperature drops close to, or even below zero degree, whole body metabolism falls to only $1-2 \%$ of basal values during hibernation of Arctic Ground Squirrels (AGS). Blood flow slows in most of the vascular system to slightly above zero and the nervous system activity is reduced (Ma et al., 2005). Yet, this state is spontaneously reversible (Heller and Ruby, 2004).

AGS, a polar hibernator, is able to endure extreme changes in endogenous $\mathrm{O}_{2}$ under different natural physiological states. During hibernation, AGS blood is well oxygenated with similar blood oxygen partial pressure $\left(\mathrm{P}_{\mathrm{a}} \mathrm{O}_{2}\right)$ as compared to non-hibernator rat brains (Ma et al., 2005), but AGS brain tissue oxygen partial pressure $\left(\mathrm{P}_{\mathrm{t}} \mathrm{O}_{2}\right)$ is low (Ma and $\left.\mathrm{Wu}, 2008\right)$. When aroused from hibernation, AGS experiences a drop in $\mathrm{P}_{\mathrm{a}} \mathrm{O}_{2}$ to $\sim 9 \mathrm{~mm} \mathrm{Hg}$, but while hypoxic there is no evidence of cellular stress, inflammatory response, neuronal pathology, or oxidative modification in brain following the period of high metabolic demand necessary for arousal (Ma et al., 2005). In their euthermic state, AGS have shown low $\mathrm{P}_{\mathrm{a}} \mathrm{O}_{2}$ and low hemoglobin oxygen saturation $\left(\mathrm{sO}_{2}\right)$ which was not observed in rats (Ma et al., 2005). However, the $\mathrm{P}_{\mathrm{t}} \mathrm{O}_{2}$ in the AGS euthermic state is higher than in the hibernating state (Ma and $\mathrm{Wu}, 2008$; Ma et al., 2009), suggesting the changes are related to $\mathrm{O}_{2}$ delivery to the brain. Regional brain blood flow (rCBF) has been observed to increase dramatically in hibernator $\mathrm{s}$ (Osborne and Hashimoto, 2003). However, since studies on the real time dynamic change in $\mathrm{P}_{\mathrm{t}} \mathrm{O}_{2}$ during arousal is sporadic, we hypothesized that $\mathrm{P}_{\mathrm{t}} \mathrm{O}_{2}$ is Interdependent of $\mathrm{T}_{\text {brain }}$ and a key component in the

Corresponding Author: Yi Long Ma, Alaska Neuroscience Program, Institute of Arctic Biology, University of Alaska Fairbanks, 902 N Koyukuk Fairbanks, 99775-7000, Alaska Fax: 907-474-7827 
arousal process. The present study demonstrated that $\mathrm{P}_{\mathrm{t}} \mathrm{O}_{2}$ showed experienced dramatic fluctuations and that these changes in $\mathrm{P}_{\mathrm{t}} \mathrm{O}_{2}$ are critical factors in the complex process of arousal from hibernation.

\section{MATERIALS AND METHODS}

Animals: All procedures were performed in accordance with and approved by University of Alaska Fairbanks Institutional Animal Care and Use (IAUC) guidelines. Arctic Ground Squirrels (AGS; Spermophilus parryii) were used for these experiments. Adult AGS of both sexes were trapped during mid-July in the northern foothills of the Brooks Range, Alaska, approximately 40 miles south of the Toolik Field Station of the University of Alaska Fairbanks $\left(68^{\circ} \mathrm{C} 38^{\prime} \mathrm{N}, 149^{\circ} 38^{\prime} \mathrm{W}\right.$; elevation $809 \mathrm{~m}$ ) and transported to Fairbanks (permit obtained from Alaska Department of Fish and Game). Ground squirrels were housed individually at $16-18^{\circ} \mathrm{C}$ and fed rodent chow, sunflower seeds and fresh carrots and apples ad libitum until mid-September when they were moved to a cold chamber set to an ambient temperature $\left(\mathrm{T}_{\mathrm{a}}\right)$ of $2^{\circ} \mathrm{C}$ and 4:20 h light: dark cycle.

Stereotaxic surgery for brain guide cannula implantation: The animals used in this proposal were male and female AGS (body mass: 650-840 g) at the time of the surgery. The surgeries for AGS were conducted in late September before hibernation. Animals fasted at least $12 \mathrm{~h}$ before the surgery. Surgeries were performed under general anesthesia with Isoflurane (Halocarbon Laboratories, River Edge, NJ), induced at $5 \%$ and maintained at $1.5-3 \%$ mixed with $100 \%$ medical grade $\mathrm{O}_{2}$ at a flow rate of $1.5 \mathrm{~L} \mathrm{~min}^{-1}$. Under strict aseptic conditions, a skin incision was made midline on the head and the working area was exposed with a retractor. The soft tissues were scraped with a surgical blade and cleaned with sterilized cottontipped applicators. After tissue cleaning on the skull, two holes ( $1.8 \mathrm{~mm}$ diameter) to accommodate the guide cannulae were made with a sterilized trephine operated by a battery-driven drill at the coordinates (AP, 13.5-14 $\mathrm{mm}$; $\mathrm{L} \pm 3.25 \mathrm{~mm}$; D, $-4.0 \mathrm{~mm}$ ) for AGS and another four holes were made with a steel burr $(0.5-\mathrm{mm}$ diameter) near the cannulae holes (two in front of and two in back of the guide cannula holes) on the skull for the foundation of dental cement. After completing the drilling process, four anchor stainless steel bone screws (BAS, West Lafayette, IN) were driven into the skull through the screw holes. Two guide cannulae (CMA11, Acton, MA) were stereotaxically positioned above the right and left striatum (AP, 13.5 or $14 \mathrm{~mm}$; $\mathrm{L} \pm 3.25$ $\mathrm{mm} ; \mathrm{D},-4.0 \mathrm{~mm})$, as previously described in detail (Osborne et al., 1999; Zhou et al., 2002; Ma and Wu, 2008) and were slowly lowered $4 \mathrm{~mm}$ from the cortical surface. All cannula coordinates are measured from the midline and Frontal Nasal Suture. Cannulae were secured to the screws with dental cement.

Antibiotics (Baytril; Bayer Corp., Shawnee Mission, $\mathrm{KS}$, dose: $5 \mathrm{mg} \mathrm{kg}^{-1}$ ) were given twice a day, 1 day before surgery and 2 days after surgery, by subcutaneous injection in the back of the neck. After surgery, animals were allowed to recover completely at room temperature and daily cleanings were performed with $3 \%$ betadine for 10-15 days. Following recovery, AGS were housed individually in a cool chamber at $2^{\circ} \mathrm{C}$ under a light regime of 12:12 h light: dark.

Calibration for $\mathrm{P}_{\mathrm{O} 2}$ electrode and thermocouple and temperature correction for $\mathrm{P}_{\mathrm{t}} \mathrm{O}_{2}$ : Calibration of $\mathrm{P}_{\mathrm{O} 2}$ electrode and thermocouple. For the measurement of $\mathrm{P}_{\mathrm{t}} \mathrm{O}_{2}$, a $\mathrm{P}_{\mathrm{O} 2}$ microelectrode (Model: IPS-020; $200 \mu \mathrm{m}$; Inter Medical Co. Ltd, Japan) was calibrated in artificial cerebral spinal fluid (ACSF in mM: $\mathrm{NaCl}: 124 ; \mathrm{Cl}: 2.7$; $\mathrm{CaCl}_{2}: 1.2 ; \mathrm{MgCl}_{2}: 0.85 ;$ D-Glucose:1.4; $\mathrm{NaHCO}_{3}: 24$, $\mathrm{pH} 7.4)$ at $37^{\circ} \mathrm{C}$ equilibrated with air $\left(21 \% \mathrm{O}_{2}\right)$ and $\mathrm{N}_{2}$ $\left(0 \% \mathrm{O}_{2}\right)$, respectively, before and after each experiment to ensure no obvious change (less than 10\%). ACSF solution in a water-circulating double layer glass beaker $(15 \mathrm{~mL})$ was thermostatically maintained at a temperature of $37^{\circ} \mathrm{C}$ by circulating an anti-freezing solution through plastic tubing connected to a circulating bath, which could change the temperature of the circulating fluids to any given temperature from -2$40^{\circ} \mathrm{C}$. Compressed air containing $21 \% \mathrm{O}_{2}$ was used to set up a standard $\mathrm{P}_{\mathrm{O} 2}$ value at a reading of $145-150 \mathrm{~mm}$ $\mathrm{Hg}$, depending on the value of atmospheric pressure during calibration and pure compressed nitrogen gas was used to set up a standard $\mathrm{P}_{\mathrm{O} 2}$ value as $0 \mathrm{~mm} \mathrm{Hg}$ on the $\mathrm{P}_{\mathrm{O} 2}$ monitor (IMP-201, Inter Medical Co. Ltd, Japan). The needle thermocouples were calibrated at 0 and $40^{\circ} \mathrm{C}$ with an accuracy of $\pm 0.1^{\circ} \mathrm{C}$ in a water circulating bath before gas sterilization.

Temperature correction for $\mathrm{P}_{\mathrm{O} 2}$ measurement. Because brain temperature varies at any given time, $\mathrm{P}_{\mathrm{t}} \mathrm{O}_{2}$ measurement had to be corrected to obtain the real physiological effect. The details of the principle and the procedures of temperature correction for $\mathrm{P}_{\mathrm{t}} \mathrm{O}_{2}$ measurement was described in $\mathrm{Ma}$ and $\mathrm{Wu}$ (2008) Ma et al. (2009) and Ma et al. (2011). Briefly, to perform such a temperature correction, the following steps were taken:

- The $\mathrm{P}_{\mathrm{O} 2}$ meter was initially calibrated to a $\mathrm{P}_{\mathrm{O} 2}$ value of $144-150 \mathrm{~mm} \mathrm{Hg}$ (the value depended on the local atmospheric pressure during calibration) when the electrode was exposed to ACSF equilibrated with compressed air $\left(21 \% \mathrm{O}_{2}\right)$ at $37^{\circ} \mathrm{C}$ and to a $\mathrm{P}_{\mathrm{O} 2}$ value of zero when ACSF was 
equilibrated with compressed nitrogen gas $(0 \%$ $\mathrm{O}_{2}$ ) at $37^{\circ} \mathrm{C}$

- Under bubbling conditions of $21 \% \mathrm{O}_{2}$ in ACSF solutions ranging in temperature from $0-40^{\circ} \mathrm{C}$, the signal outputs of the $\mathrm{P}_{\mathrm{O} 2}$ electrode $\left(\mathrm{P}_{\mathrm{O} 2}\right.$,meas. $)$ were measured

- The actual values of $\mathrm{P}_{\mathrm{O} 2}\left(\mathrm{P}_{\mathrm{O} 2 \text {,cal. }}\right)$, independent of temperature effects, were calculated at each given temperature according to the equation:

$$
\mathrm{P}_{\mathrm{O} 2 \text {, cal. }}(\mathrm{mm} \mathrm{Hg})=\left(\mathrm{P}_{\mathrm{atm}}-\mathrm{P}_{\mathrm{H} 2 \mathrm{O}}\right) * \mathrm{FO}_{2},
$$

where, the values of water vapor pressure $\left(\mathrm{P}_{\mathrm{H} 2 \mathrm{O}}\right)$ (Weast, 1968; Withers, 1977), were appropriate for a given temperature.

These data- $\mathrm{P}_{\mathrm{O} 2 \text {,meas. }}, \mathrm{P}_{\mathrm{O} 2 \text {,cal. }}$ and temperature in Celsius ( $\mathrm{t}$-)were used to derive a temperature correction factor ( $\mathrm{f}=$ $\mathrm{A} \mathrm{e}^{-\mathrm{kt}}$, where the values of $\mathrm{A}$ and $\mathrm{k}$ are determined by each electrode calibration) to calculate the actual $\mathrm{P}_{\mathrm{O} 2}$ of tissues measured at various temperatures:

$$
\mathrm{f}=\mathrm{P}_{\mathrm{O} 2}, \text { cal. } / \mathrm{P}_{\mathrm{O} 2, \text { meas. }}=\mathrm{Ae}^{-\mathrm{kt}}
$$

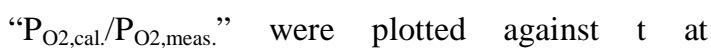
temperatures of $0-40^{\circ} \mathrm{C}$ and the curve function fitted with an Excel program to find the values of $\mathrm{A}$ and $\mathrm{k}$. After $\mathrm{A}$ and $\mathrm{k}$ values were defined, the function, $\mathrm{P}_{\mathrm{O} 2 \text {,cal. }}$. $=\left(\mathrm{Ae}^{-\mathrm{kt}}\right)\left(\mathrm{P}_{\mathrm{O} 2 \text {,meas.. }}\right)$, was programmed into the data acquisition program (PowerLab) for online temperature correction of $\mathrm{P}_{\mathrm{O} 2}$ measurements.

For each electrode and experiment, the calibration process was repeated as above.

Real-time measurement of $\mathrm{P}_{t} \mathrm{O}_{2}$ and $\mathrm{T}_{\text {brain }}$ in the striatum of AGS in conjunction with $\dot{\mathrm{V}}_{02}$. The $\mathrm{P}_{\mathrm{t}} \mathrm{O}_{2}$ in the striatum was measured by the implanted $\mathrm{PO}_{2}$ electrode, $\mathrm{T}_{\text {brain }}$ was measured by needle micro thermocouple with a tip diameter of $0.22 \mathrm{~mm}$ (HYPO33-1, Omega, Stamford, CT, USA) through guide cannula. The core body temperature was not measured in the present study because: (1) The measurement of brain temperature can more precisely reflect the regional metabolic mechanisms of the brain than the measurement of core body temperature; (2) Core body temperature $\left(\mathrm{T}_{\mathrm{b}}\right)$ could not be used for online calculation of $\mathrm{P}_{\mathrm{t}} \mathrm{O}_{2}$ because the $\mathrm{T}_{\mathrm{b}}$ changes lag behind $\mathrm{T}_{\text {brain }}$.

After animals recovered from stereotaxic surgery for brain guide cannulae implantation, the insertions of the reference electrode, the $\mathrm{P}_{\mathrm{O} 2}$ electrode and the microthermocouples were conducted under anesthesia with 2$3 \%$ isoflurane at room temperature. A sterilized silversilver chloride electrode (RC1, WPI, Sarasota, FL) was implanted to serve as a reference electrode under dorsal skin on the back through a soft silicone tube; a general anesthetic procedure with isoflurane gas was performed before insertion of the $\mathrm{P}_{\mathrm{O} 2}$ electrode and microthermocouple. After implantation of the reference electrode, the calibrated and sterilized $\mathrm{P}_{\mathrm{O} 2}$ electrode and needle micro-thermocouple for $\mathrm{T}_{\text {brain }}$ were inserted through the pre-implanted guide cannulae into the left and right striatum, respectively and secured by medical tape. The tips of the $\mathrm{P}_{\mathrm{O} 2}$ electrode and needle microthermocouple extended about $2 \mathrm{~mm}$ beyond the guide cannulae tubes. Buprenophine $\left(0.03 \mathrm{mg} \mathrm{kg}^{-1}\right)$, a pain reliever, was given by subcutaneous injection on the back, with one single dose after insertions of the $\mathrm{P}_{\mathrm{O} 2}$ electrode and thermocouple for AGS. Then for realtime in vivo recording of measurements, the animals were transferred into an experimental chamber with a normal swivel set-up for active animals. The wires connected from $\mathrm{P}_{\mathrm{O} 2}$ electrode and reference electrode to $\mathrm{P}_{\mathrm{O} 2}$ meter and from thermocouple to thermocouple meter went through a sprint tube and came out the experimental chamber in the middle of the top.

The systemic metabolic rate (oxygen consumption, $\dot{\mathrm{V}}_{02}$ ) of AGS was recorded by indirect calorimetry in a vertical cylindrical-shaped Plexiglas metabolic chamber (I.D. $29 \mathrm{~cm}$, height $32 \mathrm{~cm}$ ) previously described (Ma and Wu, 2008; Ma et al., 2009; Ma et al., 2011). Air was drawn into a distribution tube through a vertical cylindrical-shaped Plexiglas metabolic chamber at a flow rate of $3 \mathrm{~L} \mathrm{~min}^{-1}$ by a membrane pump and measured by a mass flow meter (model AFSC-10 K, Teldyne Hastings-Raydist, Hampton, VA). A separate pump sampled gas from the distribution tube through a canister, which was filled with molecular sieves and connected in a series with a Nafion drying column. $\mathrm{O}_{2}$ extraction was measured with an $\mathrm{O}_{2}$ analyzer (Model: FoxBox 2.0, Sable System International, Inc, Las Vegas, NV), which was calibrated with air. $\dot{\mathrm{V}}_{02}$ was calculated with an Excel program on the basis of the $\mathrm{O}_{2}$ fraction differences between fresh air (before being used by an animal) and expired air (after being used by an animal), flow rate of sampling air, animal body weight and a known respiratory quotient value from previous experiments with AGS (Tøien et al., 2001; Ma et al., 2005), according to Withers principles of Eq. 1:

$$
\overline{\mathrm{V}}_{02}=\mathrm{V}_{\mathrm{E}} *\left(\mathrm{~F}_{\mathrm{IO} 2}-\mathrm{F}_{\mathrm{EO} 2}\right) /\left(\left(1-(1-\mathrm{RQ}) * \mathrm{~F}_{\mathrm{IO} 2}\right)\right)
$$

The $\mathrm{P}_{\mathrm{t}} \mathrm{O}_{2}, \quad \mathrm{~T}_{\text {brain }}$ and $\dot{\mathrm{V}}_{02}$ were recorded simultaneously from $20 \mathrm{~m}$ after buprenophine injection to the end of experiment by a data acquisition program matched with the interface (Power Lab/8 sp, AD Instruments, Inc., Colorado Springs, CO) at a sample 
rate of $1 \mathrm{~min}^{-1}$ and without further signal filtering. A $\mathrm{P}_{\mathrm{O} 2}$ monitor and a thermocouple meter (Sable Systems, TC-1000 thermometer, Henderson, NV) were used as pre-amplifiers and the outputs of those two meters were connected to the interface of the data acquisition program. A Sable interface (model: U12, Henderson, $\mathrm{NV}$ ) was used as A/D converter for the $\overline{\mathrm{V}}_{02}$ measurement system. The output signals were then input into the interface of the data acquisition program. All experiments for $\mathrm{P}_{\mathrm{t}} \mathrm{O}_{2}, \mathrm{~T}_{\text {brain }}$ and $\dot{\mathrm{V}}_{02}$ measurement were conducted in the experimental chamber at $2^{\circ} \mathrm{C}$. Data in $\mathrm{P}_{\mathrm{O} 2 \text {, meas. }}$ recorded originally by the $\mathrm{P}_{\mathrm{O} 2}$ electrode in one channel were calibrated online into corresponding values of $\mathrm{P}_{\mathrm{O} 2}$,cal. without the effects of temperature in another channel.

AGS in the present study used to start to enter the hibernation two to four weeks after experiment recording for $\mathrm{P}_{\mathrm{t}} \mathrm{O}_{2}, \mathrm{~T}_{\text {brain }}$ and $\dot{\mathrm{V}}_{02}$ was set up. Data in $\mathrm{P}_{\mathrm{t}} \mathrm{O}_{2}, \mathrm{~T}_{\text {brain }}$ and $\dot{\mathrm{V}}_{02}$ were recorded continuously and collected from beginning to end of first and/or second bout of the hibernation for all AGS.

Drug administration and $\mathbf{f}_{\mathbf{R}}$ recording: The drug efaproxiral, 2-[4-[[(3, 5-dimethylanilino) carbonyl]methyl]phenoxy]-2-methylpropionic acid (RSR-13, Allos Therapeutics, Inc, Westminster, Colorado) was given as a single injection $\left(150 \mathrm{mg} \mathrm{kg}^{-1}\right)$ by i.p. The drug was provided as a solution in normal saline at concentration of $20 \mathrm{mg} \mathrm{mL}$. Saline was used as control and administrated with the same injected volume and at the same time course as drug.

Respiratory frequency $\left(f_{R}\right)$ was counted manually by direct observation during the entire experimental period with 30-min intervals beginning $60 \mathrm{~m}$ before drug administration and ending $120 \mathrm{~m}$ after drug application. Counting for $\mathrm{f}_{\mathrm{R}}$ was blindly performed by a technician.

After $\mathrm{P}_{\mathrm{t}} \mathrm{O}_{2}, \mathrm{~T}_{\text {brain }}, \mathrm{f}_{\mathrm{R}}$ and $\dot{\mathrm{V}}_{02}$ recording was completed, the animals were euthanized with isoflurane under deep anesthetic condition. The brain tissues were immediately frozen in 2-methylbutane at $-40^{\circ} \mathrm{C}$ and kept in a freezer at $-80^{\circ} \mathrm{C}$. Histologic analysis of the brains using the Cresyl Violet method to identify the $\mathrm{P}_{\mathrm{O} 2}$ electrode tip location was performed for each animal, as previously described in detail ( $\mathrm{Ma}$ and $\mathrm{Wu}$, 2008) and all tips of the $\mathrm{P}_{\mathrm{O} 2}$ electrodes were confirmed to be in the striatums.

\section{RESULTS}

Dramatic $\mathbf{P}_{\mathbf{t}} \mathbf{O}_{\mathbf{2}}$ fluctuation during arousal: Figure 1 compares changes in $\mathrm{P}_{\mathrm{t}} \mathrm{O}_{2}, \quad \dot{\mathrm{V}}_{02}$ and $\mathrm{T}_{\text {brain }}$ during a spontaneous arousal in one representative AGS, which was selected from synchronized experimental recordings of four AGS.

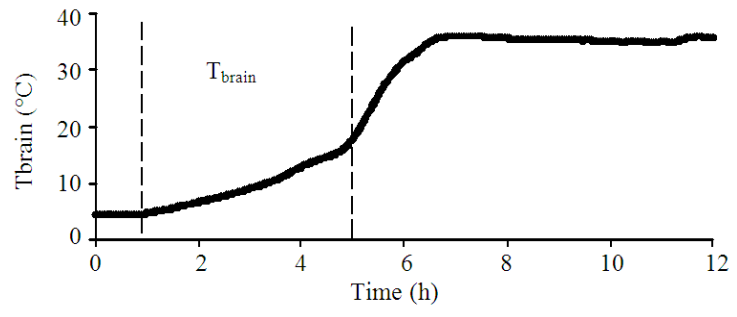

(a)

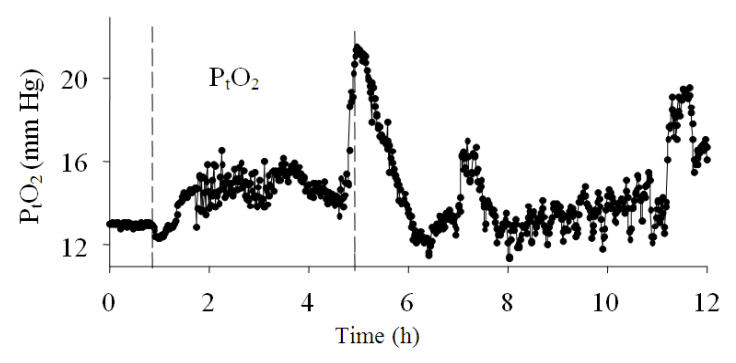

(b)

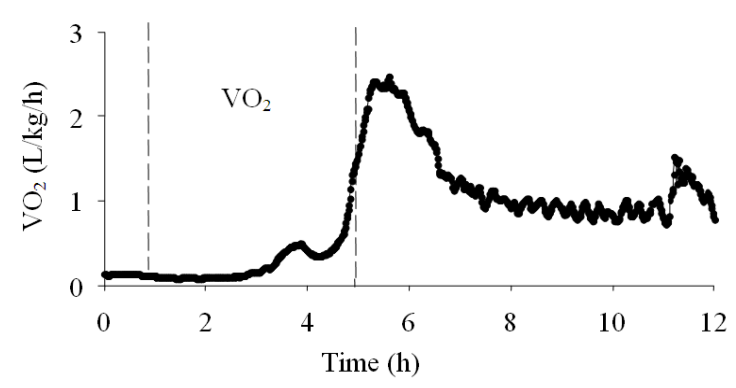

(c)

Fig. 1: $\mathrm{P}_{\mathrm{t}} \mathrm{O}_{2}$ fluctuates during arousal of AGS. The vertical dashed lines indicate the synchronized time course for $\mathrm{P}_{\mathrm{t}} \mathrm{O}_{2}, \mathrm{~T}_{\text {brain }}$ and $\dot{\mathrm{V}}_{02}$. The first dash line identifies a sudden decrease in $\mathrm{P}_{\mathrm{t}} \mathrm{O}_{2}$ from baseline at the initiation of arousal and the second vertical dashed line shows a $\mathrm{P}_{\mathrm{t}} \mathrm{O}_{2}$ peak before $\mathrm{T}_{\text {brain }}$ and $\dot{\mathrm{V}}_{02}$ peak

While a sudden drop of $\mathrm{P}_{\mathrm{t}} \mathrm{O}_{2}$ indicated by first dash line from appeared, no changes in $\mathrm{T}_{\text {brain }}$ and $\dot{\mathrm{V}}_{02}$ were observed at that point. Right after a decrease in $\mathrm{P}_{\mathrm{t}} \mathrm{O}_{2}$, $\mathrm{T}_{\text {brain }}$ begun to increase gradually and $\dot{\mathrm{V}}_{02}$ remained unchanged. After its small downward change, $\mathrm{P}_{\mathrm{t}} \mathrm{O}_{2}$ increased rapidly with a larger increase in $\mathrm{P}_{\mathrm{t}} \mathrm{O}_{2}$ approximately $0.3 \mathrm{~h}$ later. $\dot{\mathrm{V}}_{02}$ started to increase $2 \mathrm{~h}$ after the initial downward change of $\mathrm{P}_{\mathrm{t}} \mathrm{O}_{2}$. The second increase in $\mathrm{P}_{\mathrm{t}} \mathrm{O}_{2}$ occurred $4 \mathrm{~h}$ after the downward change reaching a maximum peak value as indicated by second dash line (Fig. 1). $\mathrm{T}_{\text {brain }}$ and $\dot{\mathrm{V}}_{02}$ were still increasing to their maximum values. 
Am. J. Biochem. \& Biotech., 7 (4): 163-171, 2011

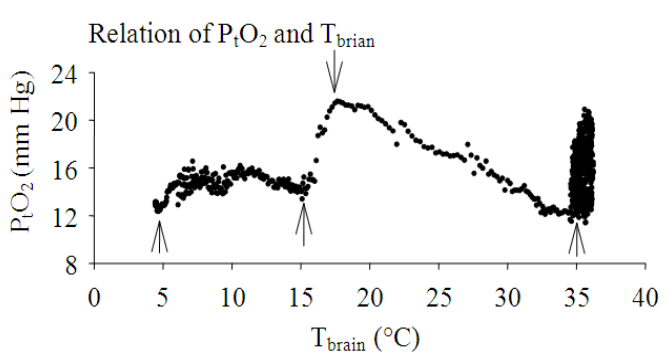

(a)

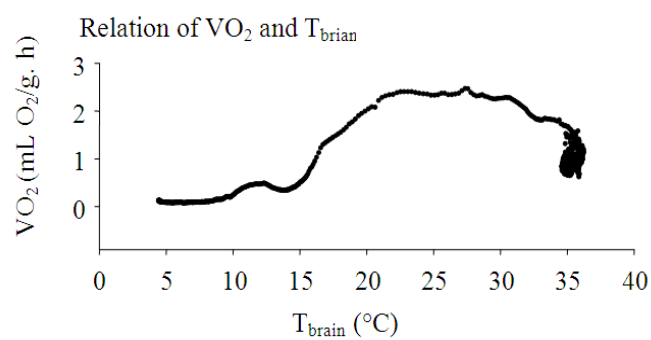

(b)

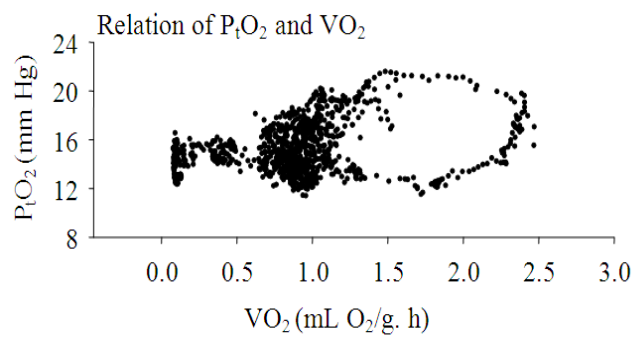

(c)

Fig. 2: Relations between $\mathrm{P}_{\mathrm{t}} \mathrm{O}_{2}, \dot{\mathrm{V}}_{02}$ and $\mathrm{T}_{\text {brain }}$ during a spontaneous arousal. $\mathrm{P}_{\mathrm{t}} \mathrm{O}_{2}$ and $\mathrm{T}_{\text {brain }} ; \mathrm{B}$. $\dot{\mathrm{V}}_{02}$ and $\mathrm{T}_{\text {brain }} ; \mathrm{C} . \mathrm{P}_{\mathrm{t}} \mathrm{O}_{2}$ and $\dot{\mathrm{V}}_{02}$

The maximum $\dot{\mathrm{V}}_{02}$ peak value reached about $0.5 \mathrm{~h}$ after the maximum $\mathrm{P}_{\mathrm{t}} \mathrm{O}_{2}$ peak value.

The maximum body temperature $\left(36.5^{\circ} \mathrm{C}\right)$ was reached almost $1 \mathrm{~h}$ after maximum $\mathrm{P}_{\mathrm{t}} \mathrm{O}_{2}$ peak value.

Using the same AGS as in Fig. 1, the correlation among $\mathrm{P}_{\mathrm{t}} \mathrm{O}_{2}, \mathrm{~T}_{\text {brain }}$ and $\dot{\mathrm{V}}_{02}$ during a natural arousal is shown in Fig. 2. The top panel, "A", in Fig. 2 shows the $\mathrm{P}_{\mathrm{t}} \mathrm{O}_{2}$ changes with $\mathrm{T}_{\text {brain }}$ during the arousal. $\mathrm{P}_{\mathrm{t}} \mathrm{O}_{2}$ was gradually increased while brain temperature rose from $5-15^{\circ} \mathrm{C}$. After brain temperature reached $15-18^{\circ} \mathrm{C}, \mathrm{P}_{\mathrm{t}} \mathrm{O}_{2}$ increased rapidly. After brain temperature was over $18^{\circ} \mathrm{C}, \mathrm{P}_{\mathrm{t}} \mathrm{O}_{2}$ declined continuously until the temperature reached $35^{\circ} \mathrm{C}$.
Panel "B" in Fig. 2 shows the $\dot{\mathrm{V}}_{02}$ changes with brain temperature during arousal. No change in $\dot{\mathrm{V}}_{02}$ was observed during $\mathrm{T}_{\text {brain }}$ increase from $5-10^{\circ} \mathrm{C}$, then showed a small increase between $10-15^{\circ} \mathrm{C}$ and rapidly increased during $15-22^{\circ} \mathrm{C}$. $\dot{\mathrm{V}}_{02}$ remained at relatively stable levels during $22-30^{\circ} \mathrm{C}$ but started to decline after brain temperature rose over $30^{\circ} \mathrm{C}$.

Panel "C" shows no correlation between $\mathrm{P}_{\mathrm{t}} \mathrm{O}_{2}$ and $\dot{\mathrm{V}}_{02}$ during arousal. This result means that $\mathrm{P}_{\mathrm{t}} \mathrm{O}_{2}$ during arousal is independent of $\dot{\mathrm{V}}_{02}$ changes.

These relationships of $\mathrm{P}_{\mathrm{t}} \mathrm{O}_{2}, \mathrm{~T}_{\text {brain }}$ and $\dot{\mathrm{V}}_{02}$ during a natural arousal indicate that complex feedbacks were occurring.

Efaproxiral induced an arousal via $\mathbf{P}_{t} \mathbf{O}_{2}$ : In order to confirm that the change in $\mathrm{P}_{\mathrm{t}} \mathrm{O}_{2}$ is related to the arousal process, the pharmaceutical agent, efaproxiral, was used to cause an endogenous increase in $\mathrm{P}_{\mathrm{t}} \mathrm{O}_{2}$. Efaproxiral increases tissue oxygen delivery by decreasing the affinity of hemoglobin for oxygen. Effectively shifting the $\mathrm{Hb}-\mathrm{O}_{2}$ dissociation curve to the right has been demonstrated in animal studies (Watson et al., 1997) and in models of human stroke (Doppenberg et al., 1997). "A" in Fig. 3 shows a representative result in changes of $\mathrm{P}_{\mathrm{t}} \mathrm{O}_{2}, \dot{\mathrm{V}}_{02}, \mathrm{~T}_{\text {brain }}$ and respiratory rate $\left(f_{R}\right)$ selected from five experimental recordings with three hibernating AGS before, during and after drug administration. Saline was injected (i.p.) at time showed by first dash line from left and no obvious $\mathrm{P}_{\mathrm{t}} \mathrm{O}_{2}$ change was observed for one $h$. Efaproxiral was then injected at time showed by second dash line. $\mathrm{A}_{\mathrm{t}} \mathrm{O}_{2}$ jump appeared approximate $5 \mathrm{~m}$ after drug injection and then $\mathrm{P}_{\mathrm{t}} \mathrm{O}_{2}$ increased gradually and reached the maximum indicated by $3 \mathrm{rd}$ and 4 th dash line. A remarkable elevation of $\mathrm{P}_{\mathrm{t}} \mathrm{O}_{2}$ values compared to control levels was obtained after drug administration. $\mathrm{P}_{\mathrm{t}} \mathrm{O}_{2}$ started to decline before $\mathrm{T}_{\text {brain }}$ and $\dot{\mathrm{V}}_{02}$ reached the maximum. Similar lag of $\dot{\mathrm{V}}_{02}$ peak and $\mathrm{T}_{\text {brain }}$ maximum following $\mathrm{P}_{t} \mathrm{O}_{2}$ elevation were observed except $f_{R}$. AGS aroused after injection of efaproxiral.

Efaproxiral increased $\mathrm{P}_{\mathrm{t}} \mathrm{O}_{2}$ and induced an arousal in all AGS. This result supports that the endogenous increase of $\mathrm{P}_{\mathrm{t}} \mathrm{O}_{2}$ is a key factor in the arousal. Efaproxiral is a good enhancer of $\mathrm{P}_{\mathrm{t}} \mathrm{O}_{2}$ by increasing $\mathrm{O}_{2}$ delivery to the brain. Also, to verify that saline injections had no chronic effect on the hibernation, two saline injections with the same volume and same time course as Efaproxiral administration were delivered to three hibernating AGS and no AGS aroused after saline injection (“ B" in Fig. 3). 
Am. J. Biochem. \& Biotech., 7 (4): 163-171, 2011

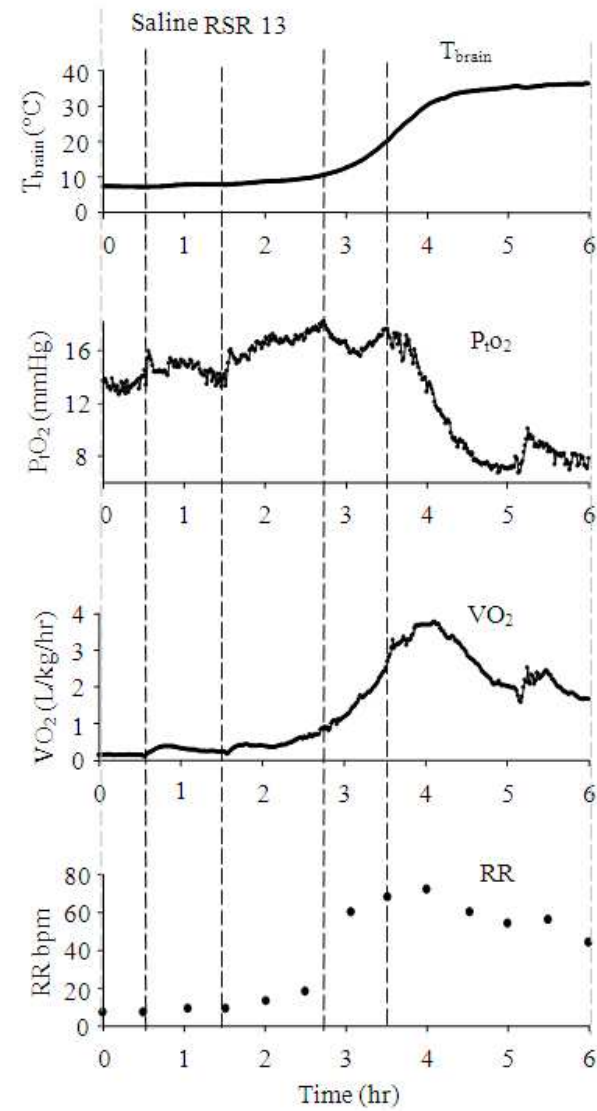

(a)
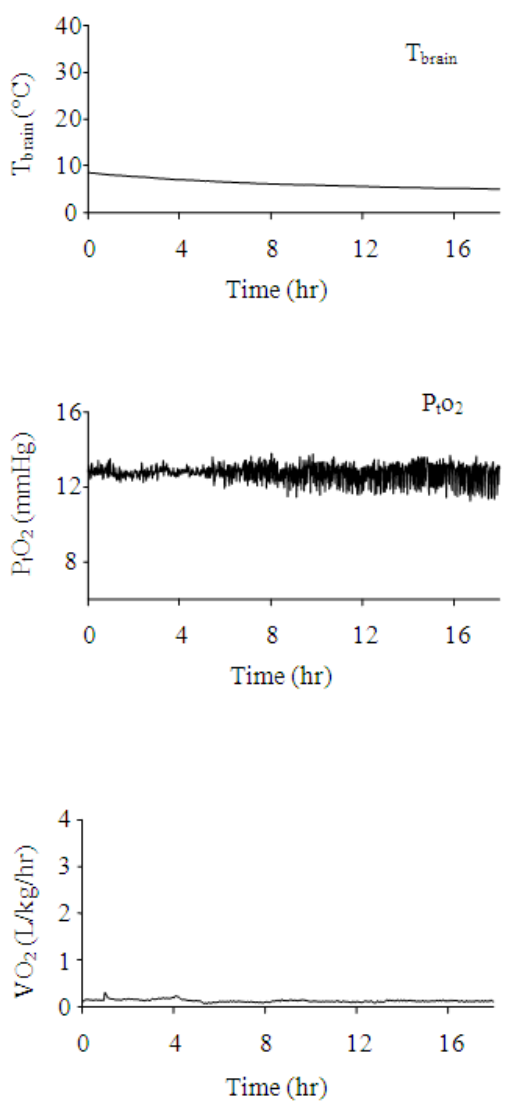

(b)

Fig. 3: A representative induced arousal by drug efaproxiral (RSR-13). A. Enhanced $\mathrm{O}_{2}$ delivery to brain with efaproxiral induces an arousal by increasing $\mathrm{P}_{\mathrm{t}} \mathrm{O}_{2}$. Saline (control) and efaproxiral are given at time showed by first and second dash line from left. The peaks in $\mathrm{P}_{t} \mathrm{O}_{2}$ are showed by $3 \mathrm{rd}$ and 4 th line. B. Saline injections have no effect on hibernating AGS. Salines with the same volume at the same time course as efaproxiral were administrated twice and no arousal was observed in $18 \mathrm{~h}$

\section{DISCUSSION}

The Central Nervous System (CNS) is considered the most sensitive organ in the body to the lack of oxygen (Milledge, 2000) because of its heavy dependence on aerobic metabolism and its high resting oxygen consumption (Davis, 1975; Kontos et al., 1978). Metabolic suppression and the complex control of thermoregulatory process have been investigated in mammalian hibernators for many years (Toien et al., 2011; Jinka et al., 2011).

Very limited evidence has shown that oxygen partial pressure $\left(\mathrm{P}_{\mathrm{O} 2}\right)$ may be involved in the modulation of CNS control of the arousal process. Oxygen levels are correlated with regulation of tissue perfusion (McCabe et al., 2003) and tissue respiration
(Hogan et al., 1992) and $\mathrm{P}_{\mathrm{O} 2}$ was supported as a messenger in metabolic control (Platzack and Hicks, 2001). The tissue oxygen concentration is a critical biochemical variable in nuclear gene expression and mitochondrial DNA-encoded complex I gene expression (Meyron-Holtz et al., 2004; Piruat and Lopez-Barneo, 2005). The present data suggests that $\mathrm{PO}_{2}$ is also involved in the complex process regulating hibernation.

The involvement of $\mathrm{P}_{t} \mathrm{O}_{2}$ in the initiation of an arousal event is demonstrated by the preceding change in $\mathrm{P}_{\mathrm{t}} \mathrm{O}_{2}$ prior to both $\mathrm{T}_{\text {brain }}$ and $\dot{\mathrm{V}}_{02}$ in Fig. 1 . The arousal begins with a sudden $\mathrm{P}_{t} \mathrm{O}_{2}$ decrease followed by a rapid jump in $\mathrm{P}_{\mathrm{t}} \mathrm{O}_{2}$ with an increase in $\mathrm{P}_{\mathrm{t}} \mathrm{O}_{2}$ levels. $\mathrm{A}$ maximum peak value of $\dot{\mathrm{V}}_{02}$ occurring during arousal supports the observations of Toien et al. (2001). In the 
present study, the delay times of the $\dot{\mathrm{V}}_{02}$ maximum showed small variations in each AGS. These delay times of the $\dot{\mathrm{V}}_{02}$ maximum are partially explained by the dead volume of the experimental Plexiglas chamber $(7.058 \mathrm{~L})$, which had a calculated delayed time that is $4.3 \mathrm{~min}$ at flushing flow rate of $3.0 \mathrm{~L} \mathrm{~min}^{-1}$ using reported method (Bartholomew et al., 1981). However, the consistent existence of this $\dot{\mathrm{V}}_{02}$ delay suggests it is a true physiological consequence of an active $\mathrm{P}_{\mathrm{t}} \mathrm{O}_{2}$ feedback during arousal in AGS. The lag time (30-45 $\mathrm{m}$ ) of $\dot{\mathrm{V}}_{02}$ reaching the maximum value compared to $\mathrm{P}_{\mathrm{t}} \mathrm{O}_{2}$ peak is shorter than the lag time for maximum

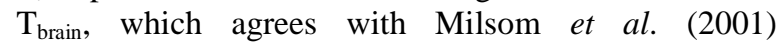
observation in which ventilation rate and metabolism increased rapidly prior to any changes in body temperature after animal become committed to the arousal process.

The correlation analysis among $\mathrm{P}_{\mathrm{t}} \mathrm{O}_{2}, \dot{\mathrm{V}}_{02}$ and $\mathrm{T}_{\text {brain }}$ during arousal (Fig. 2) gives solid support to $\mathrm{P}_{\mathrm{t}} \mathrm{O}_{2}$ feedback in the regulation of the arousal process. "C" in Fig. 2 shows that no correlation exists between $\mathrm{P}_{\mathrm{t}} \mathrm{O}_{2}$ and $\dot{\mathrm{V}}_{02}$ during arousal. The rapid jump in $\mathrm{P}_{\mathrm{t}} \mathrm{O}_{2}$ can be attributed to cardiovascular/CNS regulation of heart rate and a resulting arrhythmia during arousal. In a previous study, the change in oxygen partial pressure in arterial blood $\left(\mathrm{P}_{\mathrm{a}} \mathrm{O}_{2}\right)$ in hibernating AGS suggested that blood $\mathrm{O}_{2}$ was shunted to the brain (Ma et al., 2005). Osborne and Hashimoto (2003) observed that critical Cerebral Blood Flow (rCBF) increased dramatically during arousal. The increase in $\mathrm{rCBF}$ can be related to the change in $\mathrm{T}_{\text {brain }}$ by the demonstration that brain temperature varied with $\mathrm{rCBF}$ (Hayward and Baker, 1968; 1969).

Four turning points of $\mathrm{P}_{\mathrm{t}} \mathrm{O}_{2}$ appearing at $\mathrm{T}_{\text {brain }}$ values of $5-35^{\circ} \mathrm{C}$ during arousal may represent the critical points for $\mathrm{P}_{\mathrm{t}} \mathrm{O}_{2}$ at which some physiological and/or biochemical metabolic mechanisms were triggered and/or switched (" $\mathrm{A}$ " in Fig. 2). When $\mathrm{P}_{\mathrm{t}} \mathrm{O}_{2}$ reaches the maximum, $\mathrm{T}_{\text {brain }}$ and $\dot{\mathrm{V}}_{02}$ are still only at half of their maximum values. The increase in $\mathrm{P}_{t} \mathrm{O}_{2}$ Precedes $\dot{\mathrm{V}}_{02}$ and $\mathrm{T}_{\text {brain }}$ during arousal. All these results support that $\mathrm{P}_{\mathrm{t}} \mathrm{O}_{2}$ is a biochemical landmark for brain activity during the arousal event. Thus $\mathrm{P}_{\mathrm{t}} \mathrm{O}_{2}$ reflects an increase in CNS activity which, in turn, is a physiological prelude to whole animal arousal from torpor. The effect of efaproxiral on $\mathrm{P}_{\mathrm{t}} \mathrm{O}_{2}$ (" $\mathrm{A}$ " in Fig. 3) provides an additional support to the idea that $\mathrm{P}_{\mathrm{t}} \mathrm{O}_{2}$ levels are involved in regulating the complex process of arousal. Efaproxiral leads to the CNS enriched in $\mathrm{O}_{2}$ which is redistributed from blood $\left(\mathrm{P}_{\mathrm{t}} \mathrm{O}_{2}\right)$ (" $\mathrm{A}$ " in Fig. 3).

In summary, $\mathrm{P}_{\mathrm{t}} \mathrm{O}_{2}$ plays a key role in triggering and regulating a spontaneous arousal, which is demonstrated by: (1) a preceding $\mathrm{P}_{\mathrm{t}} \mathrm{O}_{2}$ elevation before changes in $\mathrm{T}_{\text {brain }}$ and $\dot{\mathrm{V}}_{02}$; (2) $\mathrm{P}_{\mathrm{t}} \mathrm{O}_{2}$ changes do not correlate with changes in $\overline{\mathrm{V}}_{02}$ during arousal; (3) endogenous $\mathrm{O}_{2}$ shift from $\mathrm{O}_{2}$ enriched blood to brain in hibernating AGS induces an arousal with the pharmaceutical chemical, efaproxiral (RSR-13); (4) four turning points of $\mathrm{P}_{t} \mathrm{O}_{2}$ appearing at different $\mathrm{T}_{\text {brain }}$ during arousal suggest that changes in $\mathrm{P}_{\mathrm{t}} \mathrm{O}_{2}$ are $\mathrm{T}_{\text {brain }}$ dependent.

\section{CONCLUSION}

The four turning points of $\mathrm{P}_{\mathrm{t}} \mathrm{O}_{2}$ appearing at different $\mathrm{T}_{\text {brain }}$ during arousal suggest that changes in $\mathrm{P}_{\mathrm{t}} \mathrm{O}_{2}$ are $\mathrm{T}_{\text {brain }}$ interdependent and support the concept that $\mathrm{P}_{\mathrm{t}} \mathrm{O}_{2}$ plays a key role in triggering and regulating a spontaneous arousal.

\section{ACKNOWLEDGEMENT}

We thank Dr. Kelly Drew, Dr. Brian Barnes and Dr. Michael Harris of the University of Alaska Fairbanks Institute of Arctic Biology and the late Dr. Musa Haxhiu, Rainbow Babies and Children's Hospital, Case Western Reserve University for helpful discussions over the years. We would like to thank Allos Therapeutics, Inc for providing the drug, efaproxiral and for comments on this manuscript. This study was supported by NIH grant 1 R15 NS48873-01 and NS041069-06.

\section{REFERENCES}

Bartholomew, G.A., D. Vleck and C.M. Vleck, 1981. Instantaneous measurements of oxygen consumption during pre-flight warm-up and postflight cooling in sphingid and saturniid moths. J. Exp. Biol., 90: 17-32.

Davis, J.N., 1975. Adaptation of brain monoamine synthesis to hypoxia in the rat. J. Appli. Physiol., 39: 215-220. PMID: 240796

Doppenberg, E.M.R., J.C. Watson, R. Bullock, M.J. Gerber and A. Zauner et al., 1997. The rationale for and effects of oxygen delivery enhancement to ischemic brain in a feline model of human stroke. Ann. N.Y. Acd. Sci., 825: 241-257. DOI: 10.1111/j.1749-6632.1997.tb48435.x

Hayward, J.N. and M.A. Baker, 1968. Role of cerebral arterial blood in the regulation of brain temperature in the monkey. Am. J. Physiol., 215: 389-403. PMID: 4969787

Hayward, J.N. and M.A. Baker, 1969. A comparative study of the role of the cerebral arterial blood in the regulation of brain temperature in five mammals. Brain Res., 16: 417-440. DOI: 10.1016/00068993(69)90236-4 
Heller, H.C. and N.F. Ruby, 2004. Sleep and circadian rhythms in mammalian torpor. Ann. Rev. Physiol., 66: 275-289. DOI: 10.1146/annurev.physiol.66.032102.115313

Hogan, M.C., P.G. Arthur, D.E. Bebout, P.W. Hochachka and P.D. Wagner, 1992. Role of $\mathrm{O}_{2}$ in regulating tissue respiration in dog muscle working in situ. J. Appl. Physiol., 73: 728-736. PMID: 1400003

Jinka, T.R., Q. Toien and K.L. Drew, 2011. Season primes the brain in an arctic hibernator to facilitate entrance into torpor mediated by adenosine A(1) receptors. J. Neurosci., 31: 10572-10578. PMID: 21795527

Kontos, H.A., E.P. Wei, A.J. Raper, W.I. Rosenblum and R.M. Navari et al., 1978. Role of tissue hypoxia in local regulation of cerebral microcirculation. Am. J. Physiol., 234: H582H591. PMID: 645924

Ma, Y.L., X. Zhu, P.M Rivera, O. Toien and B.M. Barnes et al., 2005. Absence of cellular stress in brain after hypoxia induced by arousal from hibernation in Arctic ground squirrels. Am. J. Physiol. Regul Integr. Comp. Physiol., 289: R1297-R1306. DOI: 10.1152/ajpregu.00260.2005 PMID: 15976308

Ma, Y. and S. Wu, 2008. Simultaneous measurement of brain tissue oxygen partial pressure, temperature and global oxygen consumption during hibernation, arousal and euthermy in non-sedated and non-anesthetized Arctic ground squirrels. J. Neurosci. Methods, 174: 237-244. DOI: 10.1016/j.jneumeth.2008.07.011

Ma, Y., S. Wu, B. Rasley and L. Duffy, 2009. Adaptive response of brain tissue oxygenation to environmental hypoxia in non-sedated, nonanesthetized arctic ground squirrels. Comp. Biochem. Physiol. Part A: Mol. Integ. Physiol., 154: 315-322. DOI: 10.1016/j.cbpa.2009.06.016

Ma, Y., S. Wu and L. Duffy, 2011. Effects of hyperoxia on brain tissue oxygen tension in nonsedated, non-anesthetized arctic ground squirrels: An animal model of hyperoxic stress. Am. J. Anim. Vet. Sci., 6: 7-17. DOI: 10.3844/ajavsp.2011.7.17

McCabe, M.G., R. Bourgain and D.J. Maguire, 2003. Oxygen As A Regulator Of Tissue Perfusion. In: Oxygen Transport to Tissue XXV, Thorniley, $\mathrm{H}$. and K. James, (Eds.). Academic/Plenum Publisher, Kluwer, pp: 287-90.

Meyron-Holtz, E.G., M.C. Ghosh and T.A. Rouault, 2004. Mammalian tissue oxygen levels modulate iron-regulatory protein activities in vivo. Science, 306: 2087-2090. DOI: 10.1126/science. 1103786
Milledge, J.S., 2000. Oxygenation of the brain at altitude. Clin. Sci., 98: 165-166. PMID: 10657271

Milsom, W.K., M.B. Zimmer and M.B. Harris, 2001. Vagal control of cardiorespiratory function in hibernation. Exp. Physiol., 86: 791-796.

Ortmann, S. and G. Heldmaier, 2000. Regulation of body temperature and energy requirements of hibernating alpine marmots (marmota marmota). Am. J. Physiol. Regul. Integ. Comp. Physiol., 278: R698-R704. PMID: 10712291

Osborne, P.G., Y. Hu, D.N. Covey, B.N. Barnes and Z. Katz et al., 1999. Determination of striatal extracellular gamma-aminobutyric acid in nonhibernating and hibernating arctic ground squirrels using quantitative microdialysis. Brain Res., 839: 1-6. PMID: 10482793

Osborne, P.G. and M. Hashimoto, 2003. Statedependent regulation of cortical blood flow and respiration in hamsters: Response to hypercapnia during arousal from hibernation. J. Physiol., 547: 963-970. DOI: 10.1113/jphysiol.2002.033571

Osborne, P.G., J. Sato, N. Shuke and M. Hashimoto, 2005. Sympathetic $\alpha$-adrenergic regulation of blood flow and volume in hamsters arousing from hibernation. Am. J. Physiol. Regul. Integr. Comp. Physiol., 289: R544-R562. DOI: 10.1152/ajpregu. 00004.2005 PMID: 15845885

Piruat, J.I. and J. Lopez-Barneo, 2005. Oxygen tension regulates mitochondrial DNA-encoded complex I gene expression. J. Biol. Chem., 280: 4267642684. DOI: $10.1074 /$ jbc.M507044200

Platzack, B. and J.W. Hicks, 2001. Reductions in systemic oxygen delivery induce a hypometabolic state in the turtle Trachemys scripta. Am. J. Physiol. Reg. Integ. Comp. Physiol., 281: R12951301. PMID: 11557639

Toien, O., K.L. Drew, M.L. Chao and M.E. Rice, 2001. Ascorbate dynamics and oxygen consumption during arousal from hibernation in arctic ground squirrels. Am. J. Physiol. Regul. Integ. Comp. Physiol., 281: R572-R583. PMID: 11448862

Toien, O., J. Blake, D.M. Edgar, D.A. Grahn and H.C. Heller et al., 2011. Hibernation in black bears: Independence of metabolic suppression from body temperature. Science, 331: 906-909. DOI: 10.1126/science.1199435

Watson, J.C., E.M. Doppenberg, M.R. Bullock, A. Zauner and M.R. Rice et al., 1997. Effects of the allosteric modification of hemoglobin on brain oxygen and infarct size in a feline model of stroke. Stroke, 28: 1624-1630. PMID: 9259760 
Weast, R.C., 1968. Handbook of Chemistry and Physics. 49th Edn., CRC, Cleveland, ISBN-10: 087819455X.

Withers, P.C., 1977. Measurement of $\mathrm{VO}_{2}, \mathrm{VCO}_{2}$ and evaporative water loss with a flow-through mask. J. Appl. Phyiol., 42: 120-123.
Zhou, F., J.F. Braddock, Y. Hu, X. Zhu and R.J. Castellani et al., 2002. Microbial origin of glutamate, hibernation and tissue trauma: An in vivo microdialysis study. J. Neurosci. Methods, 119: $121-128$. DOI: $10.1016 / \mathrm{S} 0165-$ 0270(02)00177-2 